\title{
DISTANT THUNDER Behind every good man...
}

\section{Geologist and science writer Nina Morgan wonders what went on in William Buckland's marriage}

As legend has it, it was her intellect that first attracted William Buckland [17841956] to Mary Morland [1797-1857]. The two were said to have met on a coach travelling to Dorset when both were carrying copies of Georges Cuvier's latest publication. The title is never specified, but given the timing, it may have been the final volume of Curvier's Ossemens Fossiles. Whatever the book, William and Mary fell into conversationand fell in love. They married on 31 December 1825 at Marcham, Berkshire.

Their coming together was not surprising, given her upbringing. The eldest daughter of a solicitor, Mary's mother died just over a year after Mary's birth. It was her father, who was involved in both canal promotions and coalmines in the Forest of Dean, who may have aroused her early interest in geology. Mary spent much of her childhood living in Oxford with Sir Christopher Pegge [1764-1822], Regius Professor of Anatomy, and his wife, who both admired and encouraged Mary's interest in natural history. Mary was also a skilled artist. She had been sending drawings of Megalosaurus to Curvier from 1822 and a year before her marriage had contributed a number of illustrations to William Buckland's publications.

Soon after their wedding, she and Buckland took off on a year-long wedding tour, geologising and meeting other scientists on the Continent. On their return to Oxford, she played an important role in facilitating her husband's rise as a geologist. The Oxford commentator, the Reverend William Tuckwell [1829-1919] describes her as:

"An accomplished mineralogist before their marriage, she threw her whole nature into her husband's work. She deciphered and transcribed his horribly illegible paper, often adding polish to their style; and her skilful fingers illustrated many of his books... From her came the first suggestion as to the true character of the lias [sic] coprolites. When, at two o'clock in the morning, the idea flashed upon him [Buckland] that the Cheirotherium[sic] footsteps were testudinal, he woke his wife from sleep; she hastened down to make pie crust upon the kitchen table, while he fetched in the tortoise from the garden; and the pair soon saw with joint delight that its impressions on the paste were almost identical with those upon the slabs."

\section{Standing by her man}

In 1836, Tuckwell records, when the publication of Buckland's Bridgewater Treatise:

“...roused the heresy-hunters, that a hurricane of private and newspaper protest whistled around his [Buckland's] disregarding head, that Dean Gaisford thanked God on his [Buckland's] departure for Italy - "We shall hear no more of his geology"

Tuckwell notes that Mary prevailed upon her husband to "Keep to the St James' Chronicles, everyone of which has a rap at you; but I beseech you not to lower your dignity by noticing newspaper statements..." suggesting that "Without her moral aid and intellectual support, Buckland would not so lightly and so confidently have faced his difficulties and achieved his aims."

\section{Men only}

In spite of all the intellectual power and support Mary contributed to the marriage, Buckland expressed strong opposition to the attendance of women at scientific meetings. In a letter to Roderick Murchison written in 1832 , Buckland protested against the idea of admitting women to the second meeting of the British Association:

"I was most anxious to see you talk over the proposed meeting of the British Association at Oxford in June. Everybody whom I spoke to on the subject agreed that, if the meeting is to be of scientific utility, ladies ought not to attend the reading of the papers - especially in a place like Oxford - as it would at once turn the thing into a sort of [Royal Institution] Albemarle-dilettanti-meeting, instead of a serious philosophical union of working men."

Although Buckland doesn't specify to whom the 'Everybody' in his letter refers, his objections to women were not shared by all of his contemporaries. The polymath scientist, philosopher and science historian, William Whewell [17941866], organiser of the third BA meeting and the then secretary of the BA, as well as the geologist John Phillips [18001874], were just two of the scientists who promoted the idea of 'Ladies tickets'.

\section{Opinions differ}

If William didn't appreciate the intellectual powers of women in general-and the achievements of his wife in particular-there were many others who did. Perhaps the highest accolade came from Roderick Murchison-a man notorious for not suffering fools gladly. On 5 July 1854, he wrote to Mary with an exclusive offer:

"If you had been in town, it was my intention to have begged your acceptance of my 'Siluria' ... You will be the only [ital sic] lady to whom a copy is sent, and I make this special exception out of sincere regard for yourself and gratitude to your husband, who helped an old soldier to make his way as a geologist.... Ever your sincere friend, Roderick Murchison"

End notes: Acknowledgments and sources listed online

* Nina Morgan is a geologist and science writer based near Oxford. Her latest book, The Geology of Oxford Gravestones, is available via www.gravestonegeology.uk 